\title{
Overexpression of Receptor for Advanced Glycation End Products Induces Monocyte Chemoattractant Protein-1 Expression in Rat Vascular Smooth Muscle Cell Line
}

\author{
Eri Hayakawa, Takanobu Yoshimoto, Naoko Sekizawa, Toru Sugiyama and Yukio Hirata
}

Department of Clinical and Molecular Endocrinology, Tokyo Medical and Dental University Graduate School, Tokyo, Japan

\begin{abstract}
Aim: The receptor for advanced glycation end-products (RAGE) has been suggested to play a pivotal role in the development of diabetic vasculopathy and atherosclerosis; however, due to its low expression, the physiological role of RAGE in vascular smooth muscle cells (VSMC) remains unknown. Methods: Using VSMC lines stably expressing RAGE (RAGE-A10), we studied the molecular mechanism by which $S 100 \mathrm{~B}$, a RAGE ligand, induces proinflammatory gene expression.

Results: S100B induced NF- $\kappa \mathrm{B}$ activation and the expression of several proinflammatory genes (MCP-1, IL-6, ICAM-1) at mRNA and protein levels in RAGE-A10, among which MCP-1 expression was the most robust. S100B-induced MCP-1 expression was dose-dependently blocked by inhibitors of JNK (SP600125), p38 (SB203580), MEK-1 (U0126) as well as NF- $\kappa$ B (Bay117085). In RAGE-A10, S100B activated JNK, MEK-1 and p38. S100B-induced MCP-1 promoter activity via NF- $\kappa$ B binding sites and nuclear translocation of NF- $\kappa$ B p 65 subunit were blocked by SP600125, U0126, and SB203580 in RAGE-A10.

Conclusion: Our study demonstrates that S100B increased MCP- 1 expression via NF- $\kappa$ B and mitogen-activated protein kinase (JNK, ERK1/2, and p38) pathways in RAGE-overexpressed A10 cell lines. Thus, RAGE-A10 could be a useful cell model for studying the molecular mechanism(s) of upregulated RAGE in the vasculature.
\end{abstract}

J Atheroscler Thromb, 2012; 19:13-22.

Key words; RAGE, MCP-1, JNK, Vascular smooth muscle cell

\section{Introduction}

A receptor for advanced glycation end-products (RAGE) is a member of the immunoglobulin superfamily of cell-surface molecules; however, it has been shown that RAGE, beyond its classical concept, can be activated by a wide range of endogenous ligands, such as S100/calgranulins, amphoterin and amyloid fibrils ${ }^{1)}$, which are released from injured or necrotic cells by interacting with RAGE to provoke innate immunity, providing a novel concept of "damage-associ-

Address for correspondence: Takanobu Yoshimoto, Department of Clinical and Molecular Endocrinology, Tokyo Medical and Dental University Graduate School, 1-5-45 Yushima, Bunkyo-ku, Tokyo, 113-8519 Japan

E-mail: tyoshimoto.cme@tmd.ac.jp

Received: April 4, 2011

Accepted for publication: July 28, 2011 ated molecular pattern molecules". Thus, the RAGEligand axis is appreciated as a novel key factor for chronic inflammatory diseases, such as cancer, neurodegenerative disease, and atherosclerosis ${ }^{2)}$.

Dysfunction of vascular smooth muscle cells (VSMC) has been shown to play an important role in the pathogenesis of cardiovascular diseases ${ }^{3,4)}$. It has been shown that the low basal expression of RAGE in VSMC in normal vessels ${ }^{5)}$ is markedly upregulated at the site of vascular injury ${ }^{6}$. In addition, several previous studies have shown that blockade of RAGE signaling protects against the development of atherosclerotic and neointimal vascular lesions in apoE-deficient mice and an arterial restenosis model ${ }^{7,8}$; however, few studies have reported the molecular and cellular actions of RAGE in VSMC.

To address these issues, we established stable RAGE-expressing rat VSMC lines to elucidate the cel- 
lular and molecular mechanisms downstream of RAGE activation, and revealed that S100B-induced MCP-1 expression via RAGE in VSMC is mediated by several mitogen-activated protein (MAP) kinases and $\mathrm{NF}-\kappa \mathrm{B}$-dependent pathways.

\section{Materials and Methods}

\section{Materials}

S100B protein and Dulbecco's modified Eagle's medium (DMEM) were purchased from Sigma-Aldrich (St. Louis, MO); recombinant high mobility group box 1 (HMGB1) proteins from R \& D Systems (Minneapolis, MN); Bay117085 from Biomol International (Plymouth Meeting, PA); fetal bovine serum (FBS) from Cell Culture Laboratories (Cleveland, $\mathrm{OH}$ ); QIAzol Lysis Reagent from Qiagen (Valencia, CA); Fugene 6 from Roche (Mannheim, Germany); U0126, SB203580, SP600125 from Calbiochem (San Diego, CA); PCR primers were synthesized by Griner Bio-One (Tokyo, Japan).

The retroviral plasmid (pMX-IP) and the retrovirus packaging cell line (PLAT-A) were kindly provided by Dr. T. Kitamura (University of Tokyo) ${ }^{9)}$. Immortalized human umbilical vein endothelial cell line (EAhy 926) was kindly provided by Dr C.J.S Edgell (University of North Carolina) ${ }^{10)}$.

\section{Cell Culture}

The rat aortic smooth muscle cell line, A10, was cultured in DMEM supplemented with $10 \%$ FBS, 15 $\mathrm{mM}$ HEPES buffer, $100 \mathrm{mg} / \mathrm{dl}$ glutamine, $100 \mu \mathrm{g} / \mathrm{ml}$ streptomycin and penicillin and incubated at $37^{\circ} \mathrm{C}$ in a humidified atmosphere of 95\% air-5\% $\mathrm{CO}_{2}$. Cells were passaged with $0.05 \%$ trypsin/ $0.02 \%$ EDTA.

\section{A10 Cell Lines Stably Expressing RAGE (RAGE-A10)}

A coding region of human RAGE cDNA isolated from EAhy926 total RNA by RT-PCR, was subcloned into the Sal I and Not I sites of the retroviral vector, pMX-IP. The empty vector, pMX-IP, was used as a control. Replication defective retroviruses were generated by transient transfection of these constructs into PLAT-A, using FuGene 6 Reagent. A10 cells were then infected with retroviruses as described ${ }^{9)}$. Individual colonies were positively selected and expanded in the presence of puromycin, and two RAGE-A10 clones were established.

\section{Immunohistochemical Staining}

Cells were seeded in a Lab-Tek chamber (Nalge Nunc, Rochester, NY), starved for $24 \mathrm{~h}$, pretreated with or without SP600125 $(5 \mu \mathrm{M})$, U0126 $(5 \mu \mathrm{M})$, or SB203580 $(10 \mu \mathrm{M})$ for $45 \mathrm{~min}$, and then stimulated with S100B $(10 \mu \mathrm{g} / \mathrm{ml})$ for $1 \mathrm{~h}$. Cells were fixed with ice-cold $70 \%$ acetone for $20 \mathrm{~min}$ and then incubated with anti-NF- $\kappa$ B p65 subunit antibody (sc109), (1:25; Santa Cruz Biotechnology, Santa Cruz, CA) for $1 \mathrm{~h}$ at room temperature. Secondary antibody (antirabbit IgG) conjugated to Alexa fluor 488 (1:2000; BD Pharmingen, San Diego, CA) was used to visualize primary antibody distribution. Laser scanning confocal microscopy was performed using a Carl Zeiss LSM 510 system (Carl Zeiss, Jena, Germany).

\section{Immunoblotting}

Immunoblot analysis was performed as described ${ }^{11)}$. Briefly, cells were harvested and lysed with ice-cold RIPA buffer (20 mM NaPO4 [pH7.4], 100 $\mathrm{mM} \mathrm{NaCl}, 1 \%$ IGEPAL-CA340, 0.25\% deoxycolate, $0.1 \%$ sodium dodecyl sulfate (SDS), $30 \mu \mathrm{g} / \mathrm{ml}$ aprotinin, $1 \mathrm{mmol} / \mathrm{L}$ phenylmethylsulfonyl fluoride (PMSF), and $2 \mathrm{mmol} / \mathrm{L}$ EDTA. Cell lysates $(25 \mu \mathrm{g}$ protein) were separated by $10 \%$ SDS-PAGE. After transfering to nitrocellulose membranes, the blot was incubated with antibodies against RAGE (sc5563) (1:600; Santa Cruz Biotechnology), actin (A2066) (1:1000; SigmaAldrich, St. Louis, MO), ICAM-1 (sc-1511) (1:1000; Santa Cruz Biotechnology), phospho-p38 (\#9215s) (1:1000; Cell Signaling Technology, Beverly, MA) and p38 (\#9212) (1:1000; Cell Signaling Technology), followed by a secondary antibody conjugated with horseradish peroxidase (1:30,000; GE Healthcare, Buckinghamshire, UK) and developed with the ECL Plus detection system (GE Healthcare).

\section{Quantification of mRNA by Real-Time RT-PCR}

Total RNA extraction and first-strand cDNA synthesis were performed as described ${ }^{12)}$. The sequences of PCR primer pairs were as follows: monocyte chemotactic protein-1 (MCP-1) forward, 5'- ATGCAGGTCTCTGTCACGCT -3', and reverse 5'- GGTGCTGAAGTCCTTAGGGT-3' (product size, 345 bp); intercellular adhesion molecule-1 (ICAM-1) forward, 5'- GACCCTGGAGATGGAGAAGAC -3', and reverse 5'- CTTGTCCAGGTGAGGACCATA -3' (product size, $343 \mathrm{bp}$ ); interleukin-6 (IL-6) forward, 5'- AATCTGCTCTGGTCTTCTGGAG -3', and reverse 5'- GTTGGATGGTCTTGGTCCTTAG -3' (product size, $239 \mathrm{bp}$ ); matrix metalloproteinase-9 (MMP-9) forward, 5'- GACAAGAAGTGGGGTTT CTGTC -3', and reverse 5'- TAGAGCCACGACCATACAGATG -3' (product size, 199 bp); 18s ribosomal RNA forward, 5'- GACACGGACAGGATTGACAG -3', and reverse 5'- AGACAAATCGCTCCACCAAC -3' (product size, 90 bp). Steady-state 
mRNA levels of rat MCP-1, ICAM-1, IL-6 and 18s ribosomal RNA were quantified with real-time quantitative RT-PCR using fluorescent SYBR Green technology (Light Cycler; Roche) as described ${ }^{13)}$. The quantification and calculation of mRNA levels of the target sequence were performed using 18s ribosomal RNA as an endogenous internal control ${ }^{14)}$.

\section{Enzyme-Linked Immunosorbent Assay (ELISA) for MCP-1 and IL-6}

Cells were seeded at a density of $1 \times 10^{5}$ cells/well on 12-well culture plates, starved for $24 \mathrm{~h}$ and then treated with or without S100B $(10 \mu \mathrm{g} / \mathrm{ml})$. After $24 \mathrm{~h}$ incubation, MCP-1, IL- 6 protein levels in the conditioned medium were determined using commercially available ELISA kits (Invitrogen, Carlsbad, CA).

\section{Protein Kinase Assay}

SAPK/JNK and ERK1/2 kinase activities were measured by commercially available assay kits (Cell Signaling Technology) as described ${ }^{15)}$. Briefly, $250 \mu \mathrm{g}$ cell lysate was incubated with glutathione-S transferase-c-Jun (1-89) or Elk-1 fusion protein beads at $4{ }^{\circ} \mathrm{C}$ overnight. Complexes were collected, washed, and then incubated with $50 \mu \mathrm{l}$ kinase buffer containing $100 \mu \mathrm{M}$ ATP at $30^{\circ} \mathrm{C}$ for $30 \mathrm{~min}$. The reaction was terminated with $5 x$ Lammeli sample buffer and subject to SDS-PAGE. Western blotting using phosphoc-JUN or phosphor-Elk-1 antibody was performed.

\section{Transient Transfection and Luciferase Assay}

The rat MCP-1 promoter/enhancer-driven reporter construct (pGL3-ENH), composed of a proximal promoter region and distal enhancer region containing two distinct $\mathrm{NF}-\kappa \mathrm{B}$ binding sites (A1, A2), and dual mutation at $\mathrm{A} 1$ and $\mathrm{A} 2$ (PGL3- $\Delta \kappa \mathrm{B}$ ENH) was used ${ }^{16)}$. Cells were seeded at $1 \times 10^{5}$ cells/well on 24-well culture plates. Transient transfections of $0.8 \mu \mathrm{g}$ MCP-1 reporter constructs and $0.2 \mu \mathrm{g}$ thymidine kinase promoter-driven Renilla luciferase plasmids (pRL-TK) (Promega, Madison, WI) were performed using FuGene 6 reagent as described ${ }^{16,17)}$. After $12 \mathrm{~h}$ incubation, cells were starved for $24 \mathrm{~h}$ and then treated with or without S100B (10 $\mu \mathrm{g} / \mathrm{ml})$ for $6 \mathrm{~h}$. Luciferase activities were measured by the Dual Luciferase Reporter Assay System (Promega) using Micro Lumat Plus (EG\&G Berthold, Wildbad, Germany) ${ }^{16)}$.

\section{Statistical Analysis}

Data are presented as the mean \pm SEM and were analyzed using the unpaired Student's $t$-test or ANOVA with Dunn's post-hoc test if appropriate. $p<0.05$ was considered significant. Graphpad Prism Version
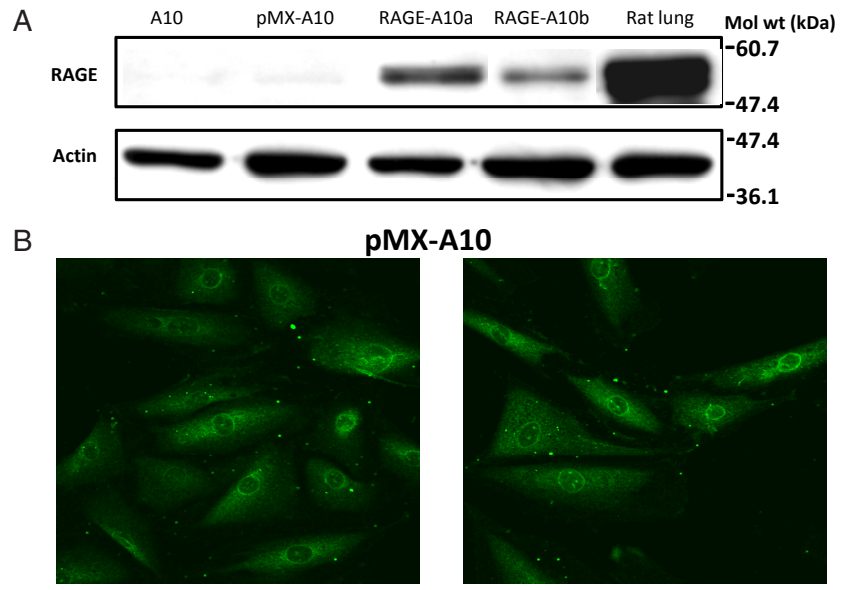

RAGE-A10

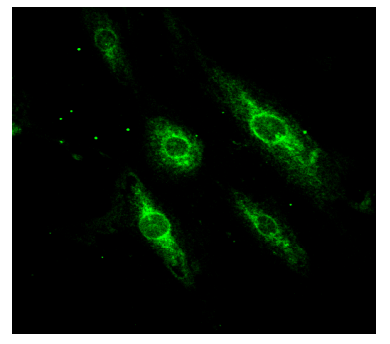

control

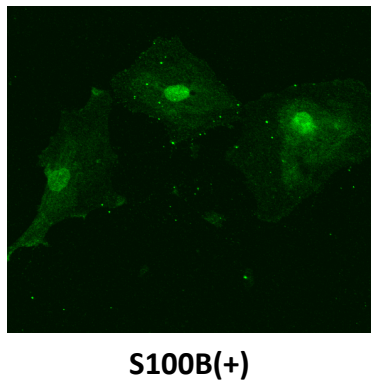

Fig. 1. Vascular smooth muscle cell lines stably expressing RAGE

(A) Immunoblotting of RAGE (upper panel) and actin (lower panel) in A10, pMX-A10, RAGE-A10 (a, b) and rat lung: Molecular weight markers $(\mathrm{kDa})$ are shown on the right. (B) Immunohistochemical staining using NF- $\kappa \mathrm{B}$ p 65 subunit antibody in control cells (pMX-A10) and RAGE-A10 cells before (left panel) and after (right panel) stimulation with S100B.

5.0 (Graphpad Software, San Diego, CA) was used for statistical analysis.

\section{Results}

\section{Stably Expressing Human RAGE-A10 Cell Lines (RAGE-A10)}

Since RAGE expression was undetectable in the primary culture of rat aortic VSMC and the A10 cell line by immunoblot analysis, the A10 cell line stably expressing human RAGE cDNA encoding full-length RAGE transcript ${ }^{18,19)}$ was established by a bicistronic retrovirus system carrying a puromycin-resistance gene. Western blot analysis revealed that two cell lines (RAGE-A10a and -A10b) had a distinct band corresponding to the molecular size $(55-\mathrm{kDa})$ of endogenous RAGE of the rat lung, whereas RAGE expression in the control cell line transfected with empty retroviral vector (pMX-A10) or in the parent A10 was barely detectable (Fig. 1A). 

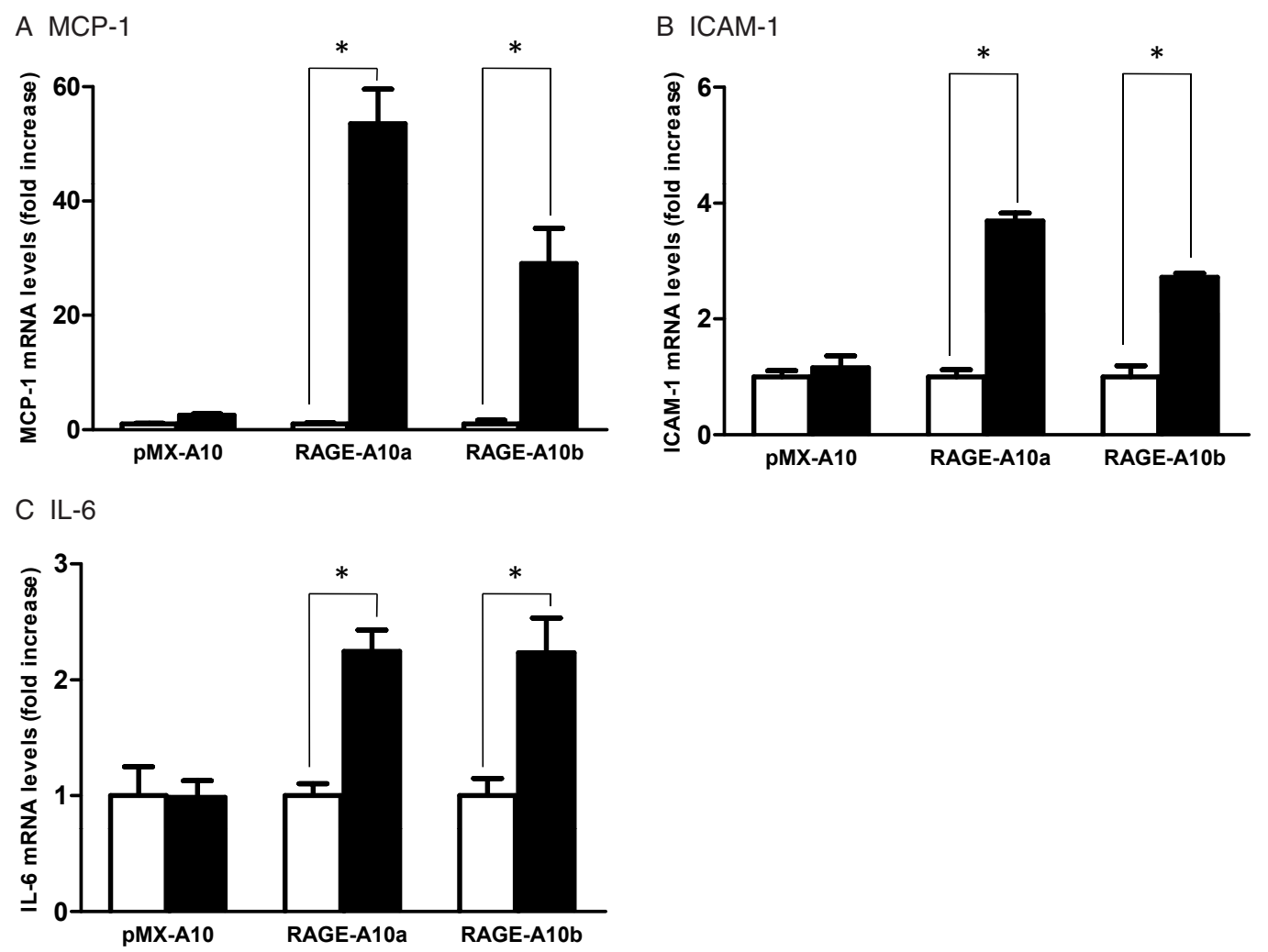

Fig. 2. S100B-induced inflammatory gene expression in RAGE-A10

RAGE-A10 and pMX-A10 cells were incubated with S100B $(10 \mu \mathrm{g} / \mathrm{ml})$ (closed column) or without (open column) for 3 h; mRNA levels of (A) MCP-1, (B) ICAM-1 and (C) IL-6 were measured by real-time RTPCR. Each column represents the mean of three independent experiments and is plotted as the fold increase over controls without S100B. Bar shows SE. ${ }^{*} P<0.05$

Immunohistochemical analysis revealed that S100B, a RAGE ligand, induced the translocation of p65 subunit of NF- $\kappa$ B from the cytosol to nucleus in RAGE-A10 (Fig. 1B, lower panel), but not in pMXA10 (Fig. 1B, upper panel). These data suggest that RAGE expressed by RAGE-A10 is functional and capable of activating the NF- $\kappa \mathrm{B}$ pathway ${ }^{20)}$.

\section{Proinflammatory Gene Expression in RAGE-A10}

We next examined whether RAGE in RAGE-A10 is involved in proinflammatory gene expression, as measured by real-time RT-PCR. As shown in Fig. 2, S100B significantly $(P<0.05)$ increased mRNA levels of MCP-1, ICAM-1, and IL-6 in two cell lines, RAGE-A10a and -A10b, but not in the control cell line (pMX-A10), in which MCP-1 gene was most robustly induced (30-50-fold).

We also examined the effect of HMGB1, another RAGE ligand, on MCP-1 expression in RAGE-A10 at various concentrations. RAGE-A10 barely responds to HMGB-1: only HMGB-1 at a very high concen- tration $(1.0 \mu \mathrm{g} / \mathrm{ml})$ was capable of increasing MCP-1 mRNA expression (Supplemental Fig. 1).

\section{S100B Induced Proinflammatory Gene Expression in a Time- and Dose-Dependent Fashion}

S100B time-dependently (1.5-12 hr) and dosedependently (1-10 $\mu \mathrm{g} / \mathrm{ml})$ increased MCP-1, ICAM-1 and IL-6 mRNA levels (Fig. 3A, B). Likewise, S100B significantly $(P<0.05)$ increased the secretion of MCP-1 and IL-6 protein and the expression of ICAM-1 protein in RAGE-A10, but not in PMX-A10 (Fig. 3C).

\section{S100B Induced MCP-1 Expression Via MAP Kinase- and NF- $\kappa$ B-Dependent Pathways}

To determine whether the NF- $\kappa \mathrm{B}$ and/or MAP kinase pathways are involved in S100B-induced MCP-1 expression in RAGE-A10, we examined the effects of various inhibitors of NF- $\kappa \mathrm{B}$ and several protein kinases (Fig.4). Bay117085, an inhibitor of NF- $\kappa$ B, dose-dependently $(1-5 \mu \mathrm{M})$ inhibited S100B-induced 
$\bar{A}$



B
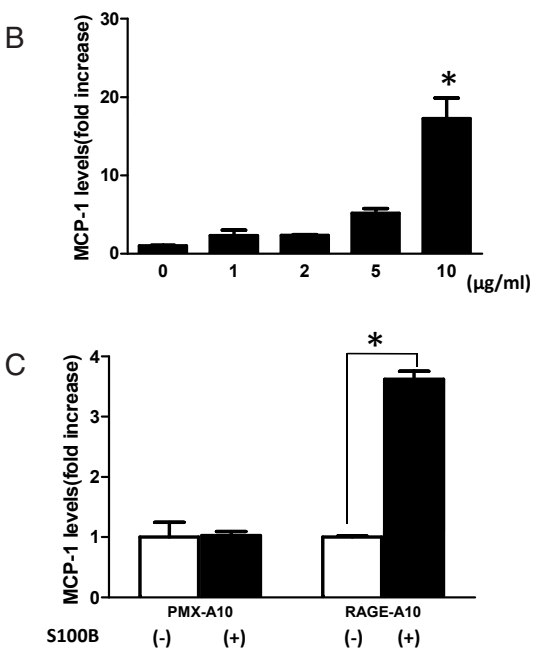
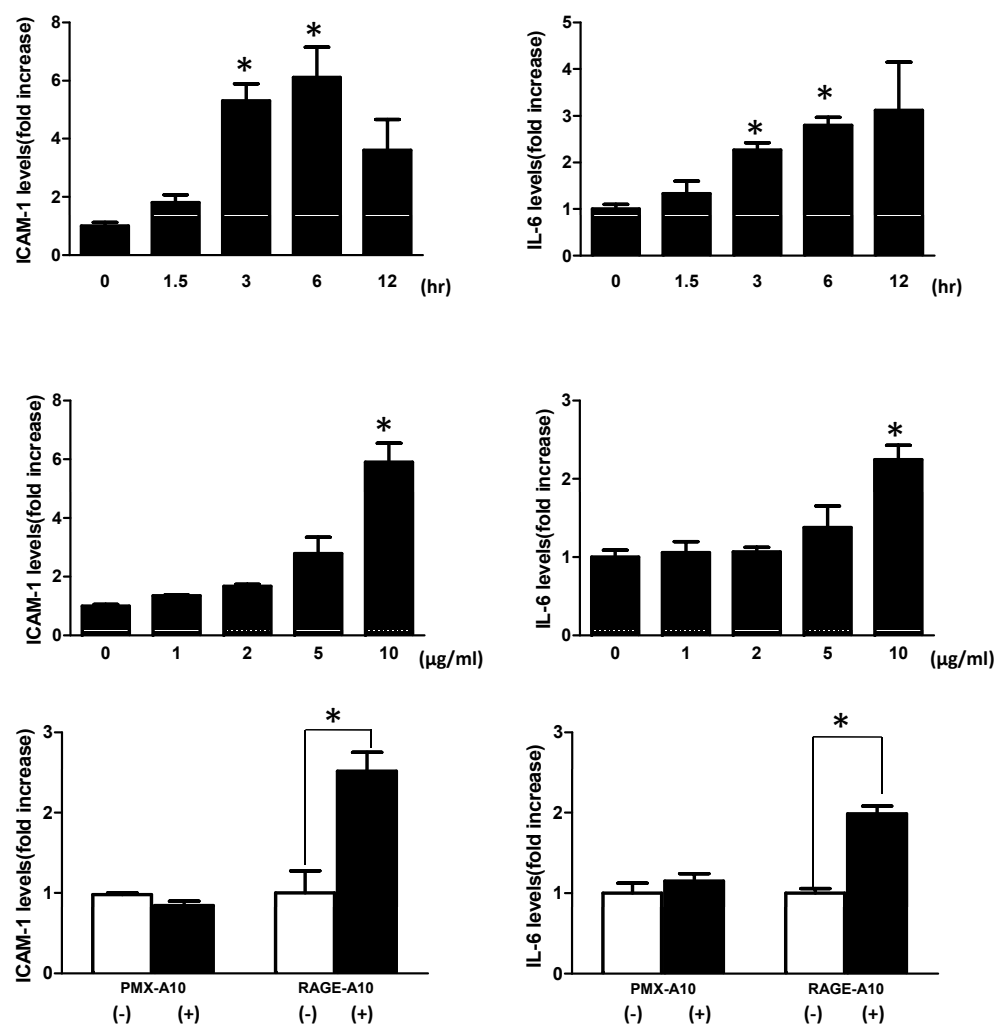

Fig. 3. S100B induces MCP-1, ICAM-1, and IL-6 mRNA and protein expression in RAGE-A10

RAGE-A10 cells were incubated with S100B $(10 \mu \mathrm{g} / \mathrm{ml})$ (A) for the indicated times and (B) at the indicated concentrations for 4.5 $\mathrm{h}$ to measure MCP-1, ICAM-1 and IL-6 mRNA by real-time RT-PCR, and (C) RAGE-A10 and pMX-A10 cells were incubated with S100B $(10 \mu \mathrm{g} / \mathrm{ml})$ for $24 \mathrm{~h}$ to measure MCP-1, IL-6 protein by ELISA and ICAM-1 protein by immunoblotting. The mean of three independent experiments was calculated and plotted as described in Fig. $2{ }^{*} P<0.05$ vs. cells without treatment.



C MEK-1 inhibiotor

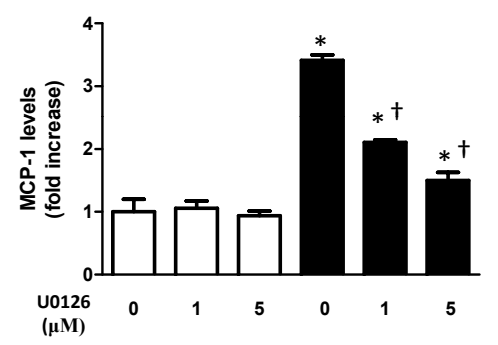

B JNK inhibitor

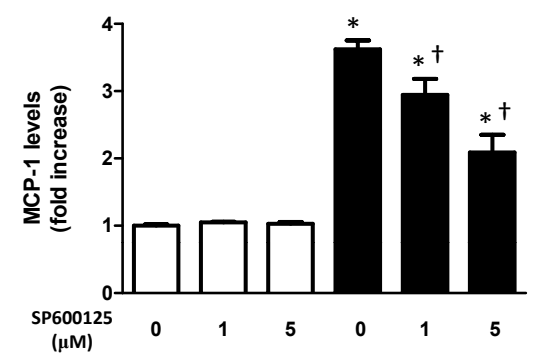

D p38 inhibitor

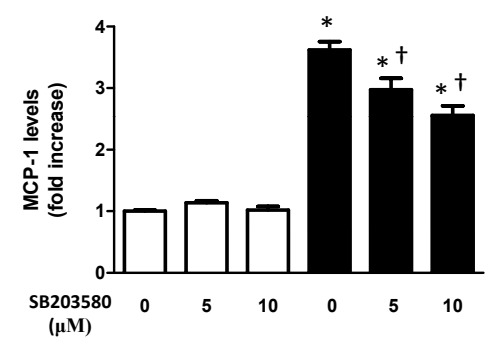

Fig.4. Effects of various inhibitors of protein kinases and $\mathrm{NF}-\kappa \mathrm{B}$ on S100B-induced MCP-1 production in RAGE-A10

After pretreatment with or without (A) Bay117085, a NF- $\kappa$ B inhibitor; (B) SP600125, a JNK inhibitor; (C) U0126, a MEK-1 inhibitor; and (D) SB203580, a p38 inhibitor at various doses, RAGE-A10 cells were stimulated with (closed column) and without (open column) S100B $(10 \mu \mathrm{g} / \mathrm{ml})$ for $24 \mathrm{~h}$ to measure MCP-1 protein by ELISA. Data were calculated and plotted as in Fig. 2. Bar shows SE. ${ }^{*} P<0.05$ vs. cells without treatment. ${ }^{\dagger} P<0.05$ vs. cells stimulated with S100B without pretreatment. 
A

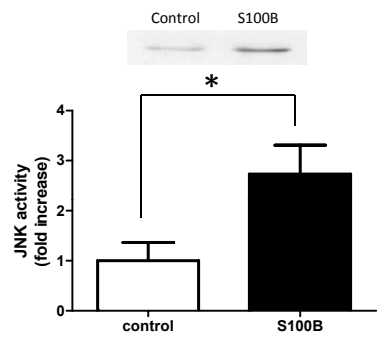

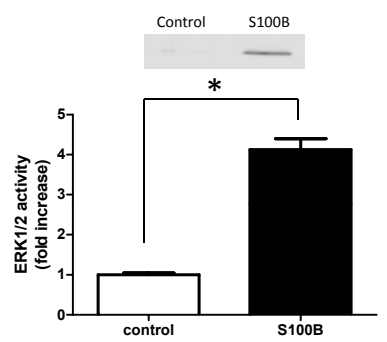

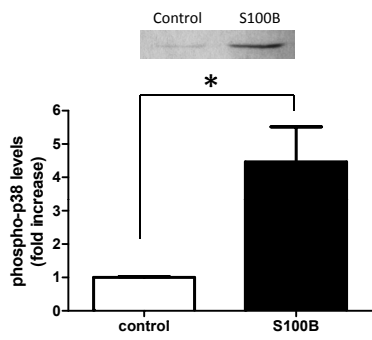

B

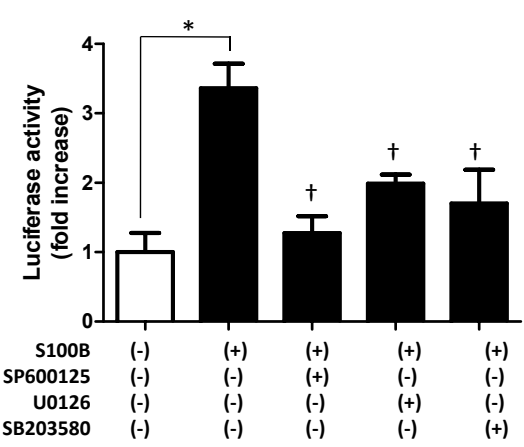

PGL3-ENH

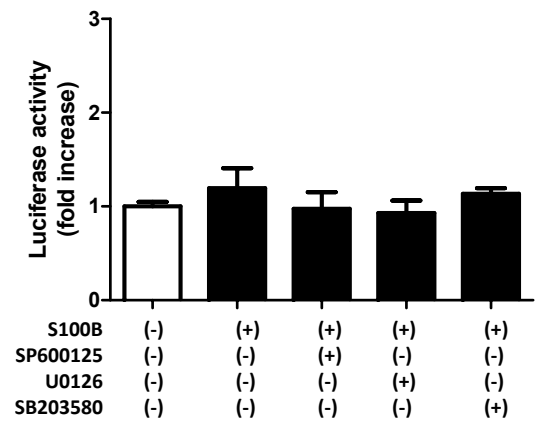

Fig. 5. JNK activation is involved in S100B-induced MCP-1 transcriptional activation through $\mathrm{NF}-\kappa \mathrm{B}$ binding sites in RAGE-A10

(A) RAGE-A10 cells were incubated with S100B $(10 \mu \mathrm{g} / \mathrm{ml})$ for $30 \mathrm{~min}$, and JNK and ERK1/2 activities and protein levels of phospho-p38 were measured. Each column represents the mean of three independent experiments and is plotted as the fold increase over controls without S100B. Bar shows SE. ${ }^{*} P<0.05$.

(B) After pretreatment with or without SP600125 $(5 \mu \mathrm{M})$, U0126 $(5 \mu \mathrm{M})$, and SB203580 $(10 \mu \mathrm{M})$ for 1 h, cells cotransfected with pRL-TK and pGL3-ENH or pGL3- $\Delta \kappa \mathrm{B}$ ENH were stimulated with (closed column) or without (open column) S100B for $6 \mathrm{~h}$; luciferase activity was then measured. Relative luciferase activities expressed as the fold increase over the control are the mean of four independent experiments. Bar shows SE. ${ }^{*} P<0.05$ vs. cells without treatment. ${ }^{\dagger} P<0.05$ vs. cells stimulated with $S 100 \mathrm{~B}$ without pretreatment.

MCP-1 expression, while SP600125 (1-5 $\mu \mathrm{M})$, a JNK inhibitor; SB203580 (5-10 $\mu \mathrm{M})$, a p38 inhibitor; and U0126 (1-5 $\mu \mathrm{M})$, a MEK-1 inhibitor similarly blocked S100B-induced MCP-1 expression in a dosedependent fashion: these inhibitors did not affect MCP-1 expression in cells without S100B stimulation (Fig.4). These data suggest that both $\mathrm{NF}-\kappa \mathrm{B}$ and MAP kinase (ERK1/2, JNK, p38) pathways are involved in S100B-induced MCP-1 expression.

We further examined the involvement of MAP kinases in RAGE-dependent MCP-1 expression in RAGE-A10. S100B significantly $(P<0.05)$ activated JNK, ERK1/2 and p38 (Fig. 5A) in RAGE-A10. We also found that S100B activated SEK-1 and MMK3/6, respective upstream kinases of JNK and p38, in RAGEA10 (Suppl.Fig. 2). By the luciferase reporter assay using MCP-1 promoter ${ }^{16)}$, S100B significantly $(P<$ $0.05)$ increased the promoter activity of pGL3-ENH, but not pGL3- $\Delta \kappa \mathrm{B}$ ENH, whose effect was inhibited by pretreatment with SP600125 $(5 \mu \mathrm{M})$, U0126 (5 $\mu$ M) and SB203580 $(10 \mu \mathrm{M})$ (Fig. 5B). Furthermore, SP600125 $(5 \mu \mathrm{M})$, U0126 $(5 \mu \mathrm{M})$ and SB203580 (10 $\mu \mathrm{M})$ blocked S100B-induced translocation of the p65 subunit of NF- $\kappa \mathrm{B}$ from the cytosol to nucleus in RAGEA10 by immunohistochemical analysis (Fig. 6). Taken together, these findings indicate that ERK, JNK and p38 pathways are activated by $S 100 \mathrm{~B}$, and each MAP kinase pathway is involved in NF- $\kappa \mathrm{B}$-dependent MCP1 expression in RAGE-A10.

\section{Discussion}

In the present study using rat VSMC lines stably expressing human RAGE cDNA (RAGE-A10), we have clearly demonstrated that a RAGE ligand (S100B) induced several proinflammatory gene expressions, such as MCP-1, IL-6 and ICAM-1, among which MCP-1 mRNA and protein expression were the most 


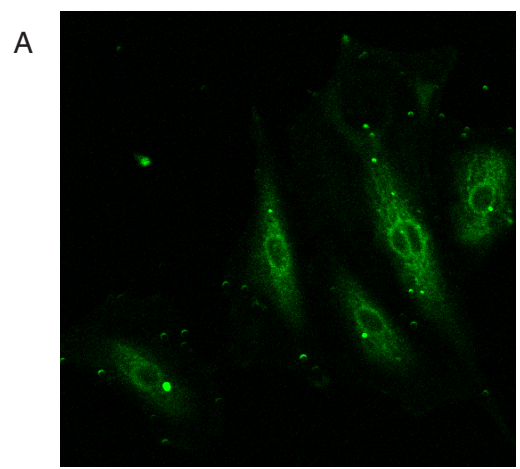

control

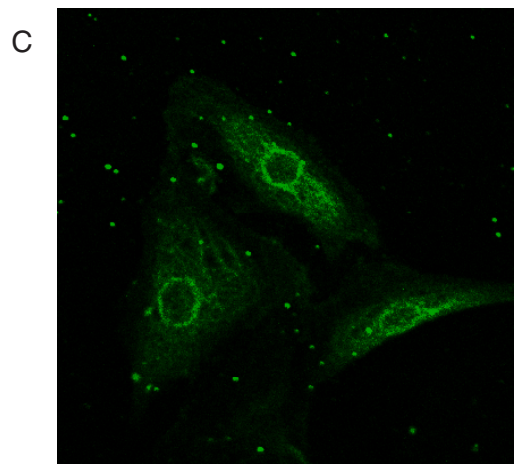

S100B+SP600125

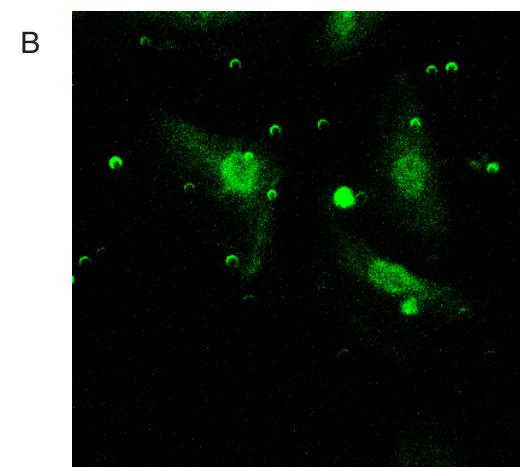

S100B

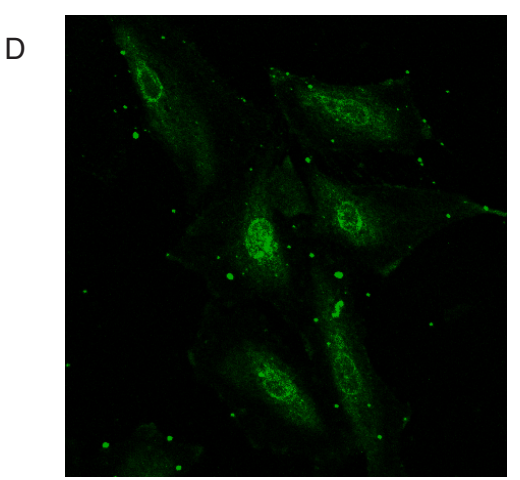

S100B+U0126

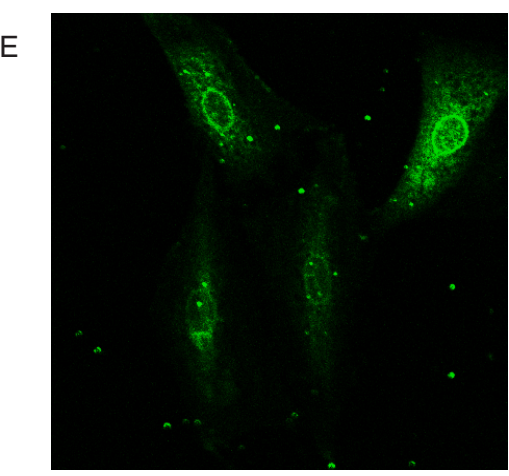

S100B+SB203580

Fig. 6. Effects of inhibitors of JNK, MEK-1, and p38 on S100B-induced nuclear translocation of NF- $\kappa$ B p65 subunit in RAGE-A10

Immunohistochemical staining using NF- $\kappa$ B p 65 subunit antibody in RAGE-A10 cells. After pretreatment without (B) or with SP600125 $(5 \mu \mathrm{M})(\mathrm{C})$, U0126 $(5 \mu \mathrm{M})(\mathrm{D})$, and SB203580 $(10 \mu \mathrm{M})(\mathrm{E})$ for $45 \mathrm{~min}$, cells were stimulated with S100B (10 $\mu \mathrm{g} / \mathrm{ml}$ ) for $1 \mathrm{~h}$. Untreated cells (A) served as a control.

robust. Furthermore, the present study showed that activation of MAP kinases (ERK1/2, p38, JNK) and $\mathrm{NF}-\kappa \mathrm{B}$ is essential for S100B-induced MCP-1 expression in RAGE-A10.

It has been shown that RAGE was upregulated at the site of vascular injury, such as neointimal lesions ${ }^{7)}$ and atherosclerotic plaque in apoE-deficient mice ${ }^{8)}$ and diabetic patients ${ }^{6}$. Blockade of RAGE signaling by soluble RAGE and gene targeting has been shown to prevent the development and/or progression of such vascular lesions; however, few studies have reported the molecular and cellular mechanisms of RAGE action in VSMCs. Recently, it has been reported that Src tyrosine kinase activated by RAGE is involved in a series of cellular responses in porcine aortic VSMC, including activation of MAP kinases and STAT3 as well as NF- $\kappa \mathrm{B}$-dependent proinflammatory gene expression ${ }^{21)}$. Very recently, it has been shown that RAGE activation is involved in the activation of the TGF- $\beta$-ROCK1 pathway in mouse aortic $\mathrm{VSMC}^{22)}$. In contrast, several previous studies have shown that cultured VSMC barely expressing RAGE were unable to respond to RAGE ligands ${ }^{5,23)}$. We also failed to detect RAGE expression and responses to S100B in our parent A10 cells and primary cultured rat VSMCs (unpublished observation). Such contradictory findings could be partly accounted for by the different species and experimental conditions. Nevertheless, several clinical and experimental animal studies have shown that RAGE expression is barely detectable or at a low level in blood vessels under normal conditions, but upregulated at the site of vascular injury $^{6,8,24)}$. These observations prompted us to establish a cell model mimicking RAGE-upregulated VSMC.

The molecular size of RAGE protein expressed in RAGE-A10 appears to be similar to that of the rat lung where RAGE is ubiquitously expressed. The present study further demonstrated that S100B, a RAGE ligand, activated the NF- $\kappa \mathrm{B}$ pathway by nuclear translocation of $\mathrm{p} 65$, a NF- $\kappa \mathrm{B}$ component. Thus, RAGEA10 could be a useful cell model for investigating the cellular and molecular mechanism by which RAGE 
exerts its effects on VSMC. Consistent with the previous study using porcine VSMC ${ }^{21)}$, S100B induced the expression of a series of NF- $\kappa \mathrm{B}$-driven proinflammatory genes (MCP-1, ICAM-1, IL-6) in RAGE-A10 at both mRNA and protein levels. Notably, S100B robustly upregulated MCP-1 mRNA and protein expressions. Since MCP-1, a pivotal chemokine, is involved in the development of atherosclerotic plaques and neointimal formation ${ }^{25,26)}$ and several previous studies have shown RAGE-dependent MCP-1 expression in VSMC ${ }^{21,27}$, RAGE-mediated MCP-1 upregulation in VSMC may contribute to the development and/or progression of such vascular lesions.

Although previous reports have shown that many biological effects of HMGB-1 were mediated by $\mathrm{RAGE}^{28,29)}$, several recent studies have clarified that purified HMGB-1 alone is not sufficient for stimulating a RAGE-mediated response ${ }^{30-32)}$ and the interactions of additional components, such as cytokines, LPS, DNA fragment, and/or interaction with Toll-like receptors, are prerequisites for its biological effects ${ }^{33-35)}$. Thus, the present finding that RAGE-A10 barely responded to HMGB-1 may lend support to the contention that HMGB-1-mediated biological effects require not only RAGE but also additional factors.

In the present study, S100B-induced MCP-1 production in RAGE-A10 was blocked by an NF- $\kappa \mathrm{B}$ inhibitor (Bay11074), suggesting that NF- $\kappa \mathrm{B}$ activation is indispensable for RAGE-mediated MCP-1 expression. The exact signaling pathways of NF- $\kappa \mathrm{B}$ activation downstream of RAGE have not been fully understood yet. Our study indicates that S100B activated JNK, ERK1/2 and p38, and inhibitors of either of the MAP kinase pathways blocked S100B-induced nuclear translocation of the p65 subunit of NF- $\kappa \mathrm{B}$ and subsequent MCP-1 production. Furthermore, the present luciferase assay using rat MCP-1 promoter containing two $\mathrm{NF}-\kappa \mathrm{B}$ binding sites revealed that JNK, ERK1/2, and p38 activations are involved in S100B-induced NF- $\kappa$ B-dependent MCP-1 promoter activation. These results collectively suggest that RAGE-mediated MAP kinase activation acts as an upstream signal of NF- $\kappa$ B activation to induce MCP-1 expression in RAGE-A10. Blockade of S100B-induced MCP-1 expression by inhibitors of MEK1 and p38, as shown in this study, is consistent with previous studies showing that both ERK1/2 and p38 are involved in RAGE-mediated NF- $\kappa \mathrm{B}$ activation and subsequent $\mathrm{MCP}-1$ expression in $\mathrm{VSMC}^{21,36)}$. Although several previous studies have shown that JNK is one of the signaling pathways downstream of RAGE in endothelial cells ${ }^{8)}$ and adventitia fibroblasts ${ }^{37)}$, the present study, to the best of our knowledge, demon- strated for the first time the role of JNK in the RAGEmediated response in VSMC. These results suggest that JNK as well as ERK1/2 and p38 plays a pivotal role in the development and/or progression of RAGEinduced vascular lesions.

As a limitation of this study, we adopted the A10 cell line in the present study, since the usage of primary VSMC culture is not suitable for establishing a stable RAGE-expressing cell line. Although the A10 cell line was derived from the thoracic aorta of embryonic rats showing combined characteristics between neonatal and neointimal VSMC ${ }^{38,39)}$ and has been used as a common cellular model of VSMC, we could not completely reject the possibility that the cellular response of A10 may not be identical to that of in vivo VSMC.

In conclusion, using rat VSMC lines stably expressing human RAGE (RAGE-A10), the present study clearly demonstrated that a RAGE ligand (S100B) stimulates $\mathrm{NF}-\kappa \mathrm{B}$ activation to induce the expression of several proinflammatory genes, among which MCP-1 expression was the most robust, and that several MAP kinases (ERK1/2, p38, JNK), are involved in S100B-induced MCP-1 expression. Thus, RAGE-A10 could be a useful cell model for investigating the molecular mechanisms of upregulated RAGE in the vasculature.

\section{Acknowledgments}

This study was supported in part by Grants-inAid from the Ministry of Education, Science, Sports and Culture, and the Ministry of Health, Welfare and Labor of Japan.

\section{References}

1) Schmidt AM, Yan SD, Yan SF, Stern DM: The multiligand receptor RAGE as a progression factor amplifying immune and inflammatory responses. J Clin Invest, 2001; 108: 949-955

2) Basta G: Receptor for advanced glycation endproducts and atherosclerosis: From basic mechanisms to clinical implications. Atherosclerosis, 2008; 196: 9-21

3) Libby P: Inflammation in atherosclerosis. Nature, 2002; 420: $868-874$

4) Ross R: Atherosclerosis--an inflammatory disease. N Engl J Med, 1999; 340: 115-126

5) Ballinger ML, Thomas MC, Nigro J, Ivey ME, Dilley RJ, Little PJ: Glycated and carboxy-methylated proteins do not directly activate human vascular smooth muscle cells. Kidney Int, 2005; 68: 2756-2765

6) Burke AP, Kolodgie FD, Zieske A, Fowler DR, Weber DK, Varghese PJ, Farb A, Virmani R: Morphologic findings of coronary atherosclerotic plaques in diabetics: a postmortem study. Arterioscler Thromb Vasc Biol, 2004; 
24: 1266-1271

7) Sakaguchi T, Yan SF, Yan SD, Belov D, Rong LL, Sousa M, Andrassy M, Marso SP, Duda S, Arnold B, Liliensiek B, Nawroth PP, Stern DM, Schmidt AM, Naka Y: Central role of RAGE-dependent neointimal expansion in arterial restenosis. J Clin Invest, 2003; 111: 959-972

8) Harja E, Bu DX, Hudson BI, Chang JS, Shen X, Hallam K, Kalea AZ, Lu Y, Rosario RH, Oruganti S, Nikolla Z, Belov D, Lalla E, Ramasamy R, Yan SF, Schmidt AM: Vascular and inflammatory stresses mediate atherosclerosis via RAGE and its ligands in apoE-/- mice. J Clin Invest, 2008; 118: 183-194

9) Kitamura T, Koshino Y, Shibata F, Oki T, Nakajima H, Nosaka T, Kumagai H: Retrovirus-mediated gene transfer and expression cloning: powerful tools in functional genomics. Exp Hematol, 2003; 31: 1007-1014

10) Edgell CJ, McDonald CC, Graham JB: Permanent cell line expressing human factor VIII-related antigen established by hybridization. Proc Natl Acad Sci USA, 1983; 80: 3734-3737

11) Yoshimoto T, Boehm M, Olive M, Crook MF, San H, Langenickel T, Nabel EG: The arginine methyltransferase PRMT2 binds RB and regulates E2F function. Exp Cell Res, 2006; 312: 2040-2053

12) Sugiyama T, Yoshimoto T, Tsuchiya K, Gochou N, Hirono Y, Tateno T, Fukai N, Shichiri M, Hirata Y: Aldosterone induces angiotensin converting enzyme gene expression via a JAK2-dependent pathway in rat endothelial cells. Endocrinology, 2005; 146: 3900-3906

13) Shichiri M, Hirata Y: Antiangiogenesis signals by endostatin. FASEB J, 2001; 15: 1044-1053

14) Sakurada M, Yoshimoto T, Sekizawa N, Hirono Y, Suzuki N, Hirata Y: Vasculoprotective effect of cilostazol in aldosterone-induced hypertensive rats. Hypertens Res, 2010; 33: 229-235

15) Yoshimoto T, Fukai N, Sato R, Sugiyama T, Ozawa N, Shichiri M, Hirata Y: Antioxidant effect of adrenomedullin on angiotensin II-induced reactive oxygen species generation in vascular smooth muscle cells. Endocrinology, 2004; 145: 3331-3337

16) Tsuchiya K, Yoshimoto T, Hirono $Y$, Tateno T, Sugiyama T, Hirata Y: Angiotensin II induces monocyte chemoattractant protein-1 expression via a nuclear factor-kappaB-dependent pathway in rat preadipocytes. Am J Physiol Endocrinol Metab, 2006; 291: E771-E778

17) Ozawa N, Shichiri M, Fukai N, Yoshimoto T, Hirata Y: Regulation of adrenomedullin gene transcription and degradation by the c-myc gene. Endocrinology, 2004; 145: 4244-4250

18) Schlueter C, Hauke S, Flohr AM, Rogalla P, Bullerdiek J: Tissue-specific expression patterns of the RAGE receptor and its soluble forms--a result of regulated alternative splicing? Biochim Biophys Acta, 2003; 1630: 1-6

19) Yonekura H, Yamamoto $Y$, Sakurai $S$, Petrova RG, Abedin MJ, Li H, Yasui K, Takeuchi M, Makita Z, Takasawa S, Okamoto H, Watanabe T, Yamamoto H: Novel splice variants of the receptor for advanced glycation end-products expressed in human vascular endothelial cells and pericytes, and their putative roles in diabetes-induced vascular injury. Biochem J, 2003; 370: 1097-1109
20) Yan SD, Schmidt AM, Anderson GM, Zhang J, Brett J, Zou YS, Pinsky D, Stern D: Enhanced cellular oxidant stress by the interaction of advanced glycation end products with their receptors/binding proteins. J Biol Chem, 1994; 269: 9889-9897

21) Reddy MA, Li SL, Sahar S, Kim YS, Xu ZG, Lanting L, Natarajan R: Key role of Src kinase in S100B-induced activation of the receptor for advanced glycation end products in vascular smooth muscle cells. J Biol Chem, 2006; 281: 13685-13693

22) Bu DX, Rai V, Shen X, Rosario R, Lu Y, D'Agati V, Yan SF, Friedman RA, Nuglozeh E, Schmidt AM: Activation of the ROCK1 branch of the transforming growth factorbeta pathway contributes to RAGE-dependent acceleration of atherosclerosis in diabetic ApoE-null mice. Circ Res, 2010; 106: 1040-1051

23) Renard CB, Askari B, Suzuki LA, Kramer F, Bornfeldt $\mathrm{KE}$ : Oleate, not ligands of the receptor for advanced glycation end-products, promotes proliferation of human arterial smooth muscle cells. Diabetologia, 2003; 46: 16761687

24) Schmidt AM, Yan SD, Wautier JL, Stern D: Activation of receptor for advanced glycation end products: a mechanism for chronic vascular dysfunction in diabetic vasculopathy and atherosclerosis. Circ Res, 1999; 84: 489-497

25) Nelken NA, Coughlin SR, Gordon D, Wilcox JN: Monocyte chemoattractant protein-1 in human atheromatous plaques. J Clin Invest, 1991; 88: 1121-1127

26) Inoue $S$, Egashira K, Ni W, Kitamoto S, Usui M, Otani K, Ishibashi M, Hiasa K, Nishida K, Takeshita A: Antimonocyte chemoattractant protein-1 gene therapy limits progression and destabilization of established atherosclerosis in apolipoprotein E-knockout mice. Circulation, 2002; 106: 2700-2706

27) Kamioka M, Ishibashi T, Sugimoto K, Uekita H, Nagai R, Sakamoto N, Ando K, Ohkawara H, Teramoto T, Maruyama Y, Takeishi Y: Blockade of renin-angiotensin system attenuates advanced glycation end products-mediated signaling pathways. J Atheroscler Thromb, 2010; 17: 590-600

28) Taguchi A, Blood DC, del Toro G, Canet A, Lee DC, Qu W, Tanji N, Lu Y, Lalla E, Fu C, Hofmann MA, Kislinger T, Ingram M, Lu A, Tanaka H, Hori O, Ogawa S, Stern DM, Schmidt AM: Blockade of RAGE-amphoterin signalling suppresses tumor growth and metastases. Nature, 2000; 405: 354-360

29) Luan ZG, Zhang H, Yang PT, Ma XC, Zhang C, Guo RX: HMGB1 activates nuclear factor-kappaB signaling by RAGE and increases the production of TNF-alpha in human umbilical vein endothelial cells. Immunobiology, 2010; 215: 956-962

30) Sha Y, Zmijewski J, Xu Z, Abraham E: HMGB1 develops enhanced proinflammatory activity by binding to cytokines. J Immunol, 2008; 180: 2531-2537

31) Youn JH, Oh YJ, Kim ES, Choi JE, Shin JS: High mobility group box 1 protein binding to lipopolysaccharide facilitates transfer of lipopolysaccharide to CD14 and enhances lipopolysaccharide-mediated TNF-alpha production in human monocytes. J Immunol, 2008; 180: 50675074

32) Qin YH, Dai SM, Tang GS, Zhang J, Ren D, Wang ZW, 
Shen Q: HMGB1 enhances the proinflammatory activity of lipopolysaccharide by promoting the phosphorylation of MAPK p38 through receptor for advanced glycation end products. J Immunol, 2009; 183: 6244-6250

33) Yu M, Wang H, Ding A, Golenbock DT, Latz E, Czura CJ, Fenton MJ, Tracey KJ, Yang H: HMGB1 signals through toll-like receptor (TLR) 4 and TLR2. Shock, 2006; 26: 174-179

34) Tian J, Avalos AM, Mao SY, Chen B, Senthil K, Wu H, Parroche P, Drabic S, Golenbock D, Sirois C, Hua J, An LL, Audoly L, La Rosa G, Bierhaus A, Naworth P, Marshak-Rothstein A, Crow MK, Fitzgerald KA, Latz E, Kiener PA, Coyle AJ: Toll-like receptor 9-dependent activation by DNA-containing immune complexes is mediated by HMGB1 and RAGE. Nat Immunol, 2007; 8: 487-496

35) Lin Q, Yang XP, Fang D, Ren X, Zhou H, Fang J, Liu X, Zhou S, Wen F, Yao X, Wang JM, Su SB: High-mobility group box-1 mediates toll-like receptor 4-dependent an-

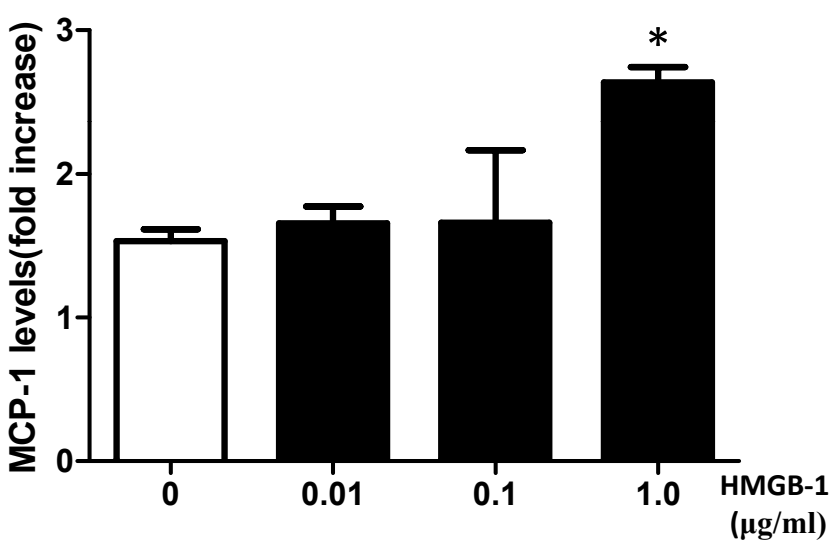

Supplemental Fig. 1. HMGB-1 barely induced MCP-1 mRNA expression in RAGE-A10

RAGE-A10 cells were incubated with (closed column) recombinant HMGB-1 at the indicated concentrations or without (open column) for $3 \mathrm{~h}$. Intracellular MCP-1 mRNA was determined by real-time RT-PCR. Each column represents the mean of three independent experiments and is plotted as the fold increase over controls without recombinant HMGB-1. Bar shows SE. ${ }^{*} P<0.05$ giogenesis. Arterioscler Thromb Vasc Biol, 2011; 31: 10241032

36) Donato R: RAGE: a single receptor for several ligands and different cellular responses: the case of certain S100 proteins. Curr Mol Med, 2007; 7: 711-724

37) Liu Y, Liang C, Liu X, Liao B, Pan X, Ren Y, Fan M, Li M, He Z, Wu J, Wu Z: AGEs increased migration and inflammatory responses of adventitial fibroblasts via RAGE, MAPK and NF-kappaB pathways. Atherosclerosis, 2010; 208: 34-42

38) Kimes BW, Brandt BL: Characterization of two putative smooth muscle cell lines from rat thoracic aorta. Exp Cell Res, 1976; 98: 349-366

39) Rao RS, Miano JM, Olson EN, Seidel CL: The A10 cell line: a model for neonatal, neointimal, or differentiated vascular smooth muscle cells? Cardiovasc Res, 1997; 36: $118-126$

a



b

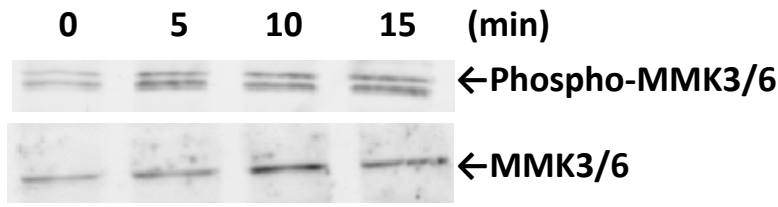

Supplemental Fig. 2. S100B induces phosphorylation of SEK-1 and MKK3/6 in RAGE-A10

RAGE-A10 cells were incubated with S100B for 0-15 min. Equal amount of cell lysates at each time point were subjected to immunoblotting with anti-phospho-SEK-1, anti-SEK-1 (a), anti-phospho-MMK3/6 and anti-MMK3/6 (b) antibodies, respectively. 